\title{
Thorsten Stoeck • Bert P. Albers \\ Microbial biomass and activity in the vicinity of a mussel bed built up by the blue mussel Mytilus edulis
}

Received: 2 May 1999 / Received in revised form: 22 November 1999 / Accepted: 6 December 1999

\begin{abstract}
Our study focuses on the impact of the biosedimentary system mussel bed (Mytilus edulis) on the spatial variability of benthic microbial biomass and activity in relation to organic deposits. We sampled a transect of six stations from the muddy mussel bed towards a reference station in the sandflat in monthly intervals for 1 year. The sediment grain size fraction $<63 \mu \mathrm{m}$ and the total organic carbon (TOC) concentration decreased significantly towards the sandflat. Bacterial numbers and total microbial biomass (total adenylates) showed a high spatial variability and were not correlated to increasing distance from the mussel bed. However, a significant relationship with the TOC concentration was found. In contrast, the energetic status (adenylate energy charge) of the microbial community in the mussel bed was significantly lower than in the sandflat. A principal component analysis of the substrate-utilization pattern revealed clear differences between the microbial communities in the mussel bed and in the sandflat. Our results indicate that the sandflat may be dominated by a relatively specialized benthic microbial community with an increased efficiency in utilizing organic carbon sources. As a disadvantage, however, such r-strategists are only able to meet environmental changes within a comparatively narrow range. Benthic microbial communities in the vicinity of an M. edulis mussel bed, in contrast, are dominated by relative generalists with a greater physiological capacity to buffer discrete environmental changes. Such $\mathrm{K}$-strategists show a lack of specialization which gener-
\end{abstract}

Communicated by H.-D. Franke

T. Stoeck ( $)$ B.P. Albers

Carl von Ossietzky-Universität Oldenburg,

Institut für Chemie und Biologie des Meeres (ICBM),

Meeresstation, Schleusenstrasse 1, 26382 Wilhelmshaven,

Germany

Present address:

T. Stoeck, Senckenberg Institut, Meeresforschung,

Schleusenstrasse 39a, 26382 Wilhelmshaven, Germany

e-mail: thorsten.stoeck@sam.terramare.de

Tel.: +49-4421-94750, Fax: +49-4421-944-19 ally means a reduced efficiency in utilizing a particular resource.

Key words Benthic microbial biomass and activity • Biodeposition $\cdot$ Mytilus edulis $\cdot$ r-/K-strategy $\cdot$ Wadden Sea

\section{Introduction}

Mussel beds of Mytilus edulis are known to build up a special ecological niche in intertidal Wadden Sea areas (Janke and Kremer 1990). Mussels function as a filter, feeding on plankton organisms in the water column. They cause the deposition of a great amount of suspended matter as faeces and pseudofaeces, and form a thick layer of mud underneath and around the mussel bed (Dankers and Zuidema 1995). This layer is rich in organic material which is mainly decomposed by bacteria and meiofauna (Dankers et al. 1989). Microorganisms, especially bacteria, are the first colonizers of the biodeposits (Prieur et al. 1990) and allow rapid mineralization of the faecal material (Stuart et al. 1982). Thus, mussel beds of M. edulis couple the pelagic and benthic systems (Asmus and Ruth 1994).

In contrast to the role of biodeposition by M. edulis in the circulation of organic matter and nutrients (Kautsky and Evans 1987; Grenz et al. 1990), little is known about the in situ influence of suspended material on biotic components in intertidal ecosystems. Information about the relationship between the organic deposits and microbial communities in the vicinity of a mussel bed is scarce.

In our paper we present results on the spatial distribution of the bacterial and microbial biomass, their energy metabolism, and changes in the microbial community in the vicinity of an M. edulis mussel bed in the German Wadden Sea. Due to the biosedimentary properties of an M. edulis bed (Dankers and Zuidema 1995) we expected a decisive influence of this system on sediment composition and on the diversity of nearby benthic 
Fig. 1 Study area in the German Wadden Sea. Mussel bed and sampling stations $(A-F)$ are marked. Situation in March 1995. Due to predation the newly settled mussel bed south of station E disappeared during summer 1995

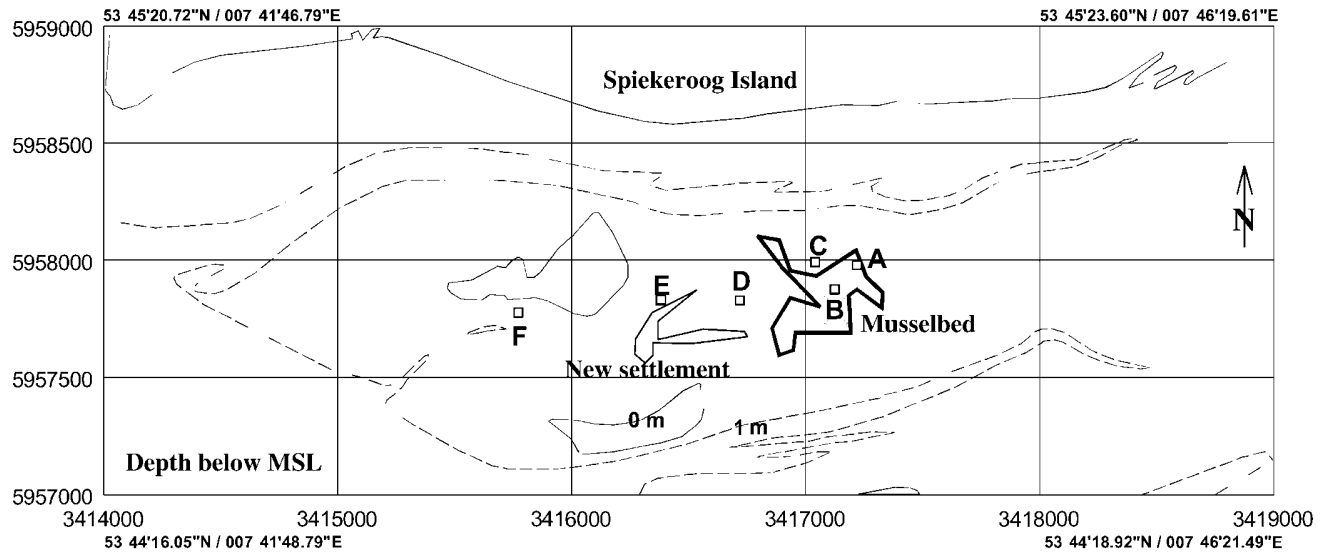

microbial communities. The study focuses mainly on sediment properties, total organic carbon (TOC) content, bacterial biomass, microbial biomass, microbial activity, and the substrate utilization pattern as a measure of the functional diversity of a microbial community (Zak et al. 1994).

\section{Materials and methods}

Area of investigation

We sampled a transect on the back barrier tidal flat "Swinnplate" in the extensive tidal system south of the island of Spiekeroog in the German Wadden Sea. A mussel bed built up by the blue mussel Mytilus edulis had established in the middle of this tidal flat.

The transect with six sample stations was arranged in the direction of the ebb-tide stream extending over $2.3 \mathrm{~km}$ (Fig. 1). The first station (A) was located in the mussel bed. The blue mussels which characterized this station were aged 5-6 years. The second station (B) was situated in a mussel bed with aggregated younger mussels (about 3 years old). Stations C, D and E were following the ebb-tide stream in a western direction. Sample station F represented the reference site in the sandflat.

\section{Sampling design}

To record spatial and temporal variability of the system, each transect station was sampled monthly from March to December 1995. Due to bad weather conditions we were not able to sample the transect in November. Samples were taken using a corer $6 \mathrm{~cm}$ in diameter. We sliced the core into subsamples from the sediment surface $(0-2 \mathrm{~cm})$ and from a depth of 7-9 cm.

Physical parameters

\section{Grain size distribution}

The grain size distribution at each station was analyzed using the Laser Particle Sizer 'Analysette 22 Economy' (Fritsch, Germany). Therefore, fresh sediment was homogenized, frozen at $-20^{\circ} \mathrm{C}$ and freeze dried. Samples were sieved with a $1000 \mu \mathrm{m}$ sieve to remove shell particles and macroalgae, then homogenized and divided into three subsamples. An aliquot of the samples was placed in the Laser Particle Sizer, and automatically homogenized by a stirrer and by ultrasonification. In this study we measured the percentage of different grain size fractions, and we considered the grain size fraction $<63 \mu \mathrm{m}$ as the mud content $(\%)$ of the sediment.
Total organic carbon

The total organic matter was determined by ashing the samples overnight at $550^{\circ} \mathrm{C}$. This was converted to TOC using a conversion factor of 2.1, which was calculated from a subset of the samples $(n=20)$ measured with an Heraeus $\mathrm{C} / \mathrm{N}$ analyzer. To remove carbonates the sediment was acidified with $\mathrm{HCl}$.

\section{Dry bulk densities}

Dry bulk densities were determined using subsamples of $10 \mathrm{ml}$, dried overnight at $110^{\circ} \mathrm{C}$.

Microbial parameters

\section{Total adenylates and adenylate energy charge}

Adenylate measurements were performed according to Albers and Stoeck (1998) who modified the original protocol of Albers et al. (1996) for marine sediments. Fifteen grams of fresh sediment was extracted with dimethylsulfoxide, $\mathrm{Na}_{3} \mathrm{PO}_{4}(0.01 \mathrm{M})$ and $\mathrm{NRB}$ (nucleotide releasing reagent for microbial ATP, Lumac, The Netherlands). After conversion of the adenosine compounds with chloroacetaldehyde yielding ethano-adenosine phosphates, the adenylates were determined by HPLC with a fluorescence detector using an excitation of $290 \mathrm{~nm}$ and an emission of $410 \mathrm{~nm}$. The measurements were repeated at least three times.

The total adenylate concentration (At), expressed in micrograms per milliliter, was calculated as the sum of the adenylates AMP, ADP and ATP. The adenylate energy charge (AEC) was calculated by the equation $\mathrm{AEC}=\mathrm{ATP}+(0.5 \times \mathrm{ADP}) /(\mathrm{AMP}+\mathrm{ADP}+$ ATP), given in molar concentrations (Atkinson and Walton 1976). The recovery rates $(89 \% \pm 6 \%)$ were obtained after addition of $4 \mathrm{ng}$ of each of the three adenylates to the sample. The recovery of adenosinephosphates in the muddy sediment did not differ significantly from that of coarser sediments and thus values were not corrected for recovery.

\section{Bacterial numbers}

The bacterial numbers were quantified using a combination of different methods (Dale 1974; Dye 1983; Epstein and Rossel 1995). Fresh sediment $(0.15 \mathrm{~g})$ was stirred with $5 \mathrm{ml}$ of sterile seawater containing EDTA and formol in a final concentration of $5 \mathrm{mM}$ and $3.7 \%$, respectively, for at least $1 \mathrm{~min}$. After incubation of the mixture for $30 \mathrm{~min}$ at room temperature, the sample was ultrasonicated. Sonification was performed with an ultrasonic processor (Soniprep 150 , MSE, Germany) at 18 microns for $2 \times 30 \mathrm{~s}$ in a $1-$ min interval. Afterwards the sample was stirred again as described above. This procedure was repeated three times. Subsequently, the mixture 
was centrifuged at $500 \mathrm{~g}$ for $5 \mathrm{~min}$. A 5 -ml aliquot of the homogenized supernatant was stained with the fluorescent dye Hoechst 33342 (Sigma) for $90 \mathrm{~min}$ at $37^{\circ} \mathrm{C}$, and filtered on a black polycarbonate membrane filter $(0.2 \mu \mathrm{m}, 25 \mathrm{~mm}$, Costar). Three replicates of each sample were counted with an epifluorescent microscope (Zeiss Axiophot) using an excitation of $395 \mathrm{~nm}$ and an emission of $420 \mathrm{~nm}$. Recovery was determined by incubating a sediment sample for $24 \mathrm{~h}$ with the added bacteria originating from a stock of non-determined marine benthic organisms. With recovery rates of 98\% for sand samples and $95 \%$ for mud samples, the applied protocol turned out to be more efficient for the investigated sediments than standard protocols in the present literature.

\section{Substrate utilization profiles}

Microbial substrate response was measured using the microplates BIOLOG GN (BIOLOG Inc., Hayward, USA) as described by Albers and Knauth-Köhler (1998).

Measurement of the carbon source fingerprints was performed with samples originating from mussel bed stations $\mathrm{A}$ and $\mathrm{B}$, as well as from the station E $1500 \mathrm{~m}$ from the mussel bed and from the reference station $F$ in the sandflat. Surface samples were taken in May, July and October 1995. Two replicates of the sediment sample were diluted 1:100 (v/v) with artificial seawater (containing $16 \mathrm{~g} \mathrm{l}^{-1} \mathrm{NaCl}, 7 \mathrm{~g} \mathrm{l}^{-1} \mathrm{MgSO}_{4} \times 7 \mathrm{H}_{2} \mathrm{O}, 0.075 \mathrm{~g} \mathrm{l}^{-1} \mathrm{NaHCO}_{3}$, $0.01 \%$ Tween 80 ). They were carefully mixed and sonicated for $30 \mathrm{~s}$ in a water bath and $100 \mu \mathrm{l}$ of the continuously mixed suspension were inoculated in each well of the microplates. Immediately after inoculation, the absorption of the samples was measured at a wavelength of $590 \mathrm{~nm}$. For microplate readings we used the Microstation (BIOLOG, Inc.). All plates were incubated for $48 \mathrm{~h}$ at $28^{\circ} \mathrm{C}$ in the dark. The optical density (OD) development was measured after $15 \mathrm{~h}, 24 \mathrm{~h}, 30 \mathrm{~h}$ and $48 \mathrm{~h}$. To control the absorption measurement, the plates were also analyzed visually after $24 \mathrm{~h}$ and $48 \mathrm{~h}$.

The OD at the beginning of the measurements as well as the absorption of the control well were subtracted from absorption in each sample well. The principal component analysis (PCA) was performed using log-transformed data from the 48-h measurement for each carbon source as a variable. The functional diversity was calculated using a modified Margalef index $D_{\mathrm{mg}}=(S-1) / \ln N$, where
$S$ is the number of substrates used and $N$ the sum of activities (absorption units).

\section{Statistical analyses}

Median values as well as their 95\% confidence intervals were calculated according to Sachs (1992). Significant interrelations between the transect stations and the measured variables were calculated using the non-parametric Spearman's rank test. The correlation between different variables was ascertained using the Pearson moment correlation, differences in mean values between horizontal and vertical distributions, respectively, were tested by Student's $t$-test. If the data set was not normally distributed (KolmogorovSmirnov test), values were standardized using log-transformation. All statistical evaluations were carried out with STATISTICA release 5.1. (StatSoft Inc. USA).

\section{Results}

\section{Sediment mud content}

The mud content in the surface sediment (Fig. 2, above left) and at a depth of 7-9 cm (Fig. 2, above right) is given for each station. The mud content decreases significantly with increasing distance from the mussel bed towards the sandflat (Spearman's $r=-0.5978, P<0.01$ ). The relationship between the distance $x(\mathrm{~m})$ and the mud content (wt \%) can be exponentially fitted in the superficial sediment by the equation mud content $=44.78 \mathrm{e}^{-0.0009 x}$ $\left(r^{2}=0.8955\right) "$ and in the 7-9 cm layer by mud content $=34.65 \mathrm{e}^{-0.0009 x} \quad\left(r^{2}=0.8293\right)$. Significant differences were found between the mean values of the mussel bed (overall mean 47\%) and the sandflat (mean 14\%). Although the mud content in deeper layers was generally lower than in surface sediments, no statistical significance could be detected.
Fig. 2 Median values and 95\% confidence intervals $(n=9)$ of the mud content (grain size fraction $<63 \mu \mathrm{m})$ (above) and total organic carbon (TOC) concentrations (below) at the sediment surface (left) and at a sediment depth of 7-9 cm (right) in relation to the distance from the mussel bed. Significant interrelationships between the values and the distance were fitted (dotted lines) using an exponential equation (see text)
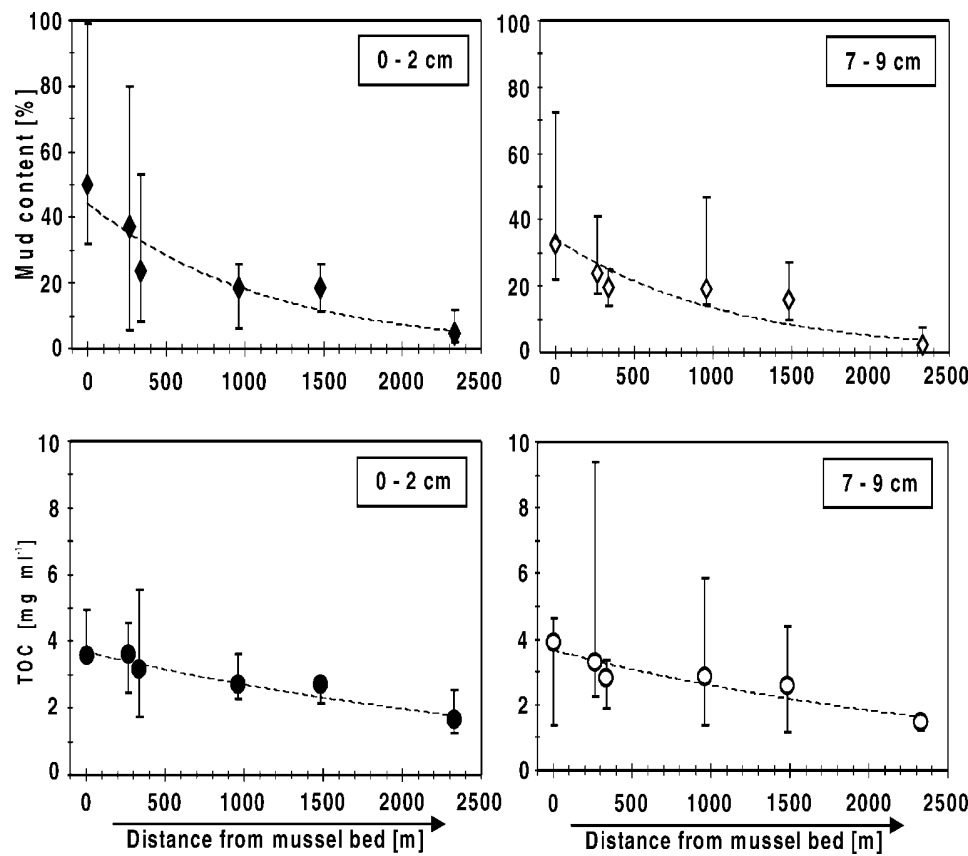
Fig. 3 Median values and 95\% confidence intervals $(n=9)$ of bacterial numbers (above), total adenylate concentration $\left(A_{\text {total }}\right.$, middle) and adenylate energy charge $(A E C$, below) at the surface (left) and at 7-9 $\mathrm{cm}$ depth (right) in relation to the distance of the mussel bed. Significant interrelationships between values and distance were fitted (dotted lines) using an exponential equation (see text). n.m.=Not measured
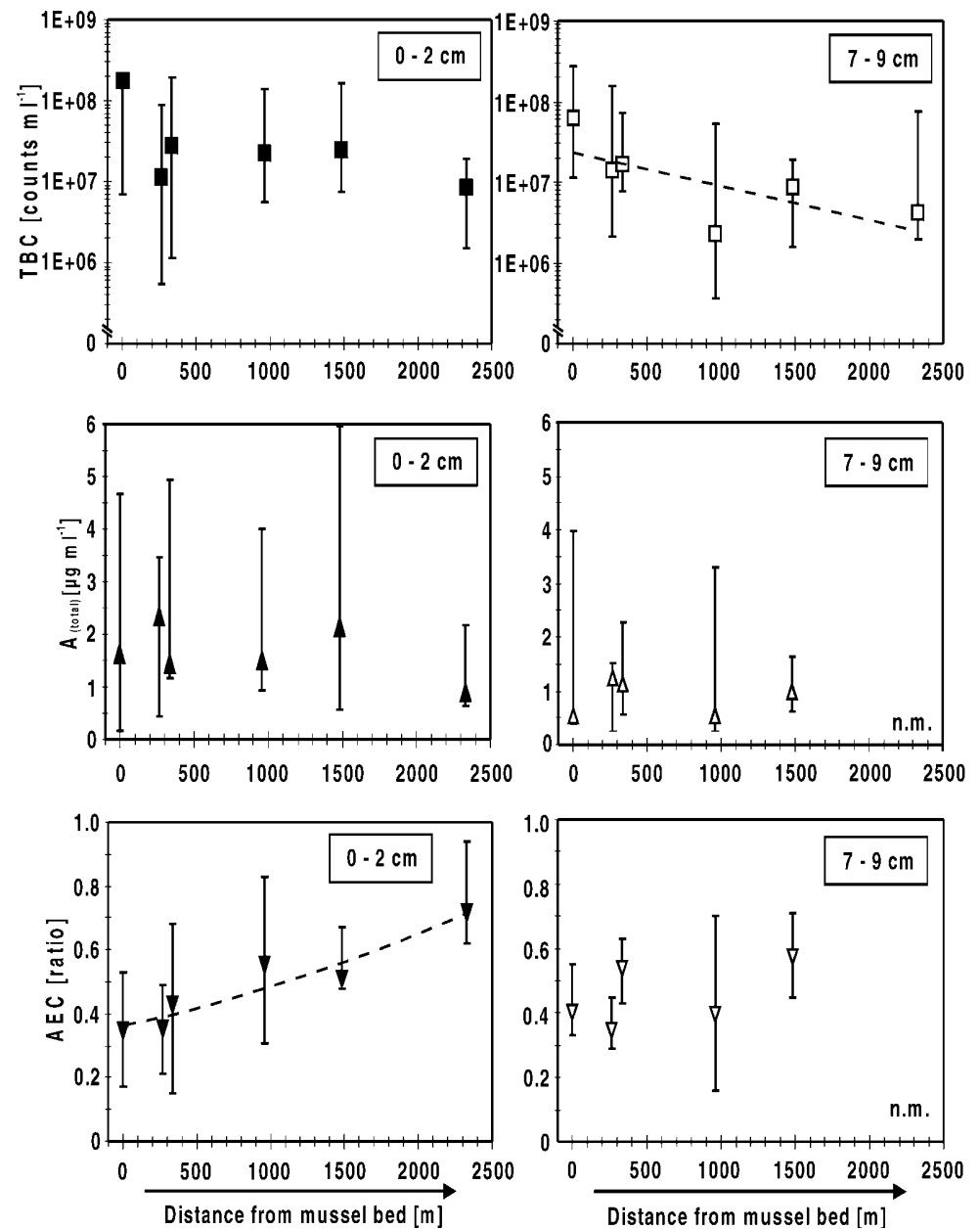

Total organic carbon

The TOC concentration significantly differed $(P<0.001)$ between the stations in the mussel bed (mean value $3.57 \mathrm{mg} \mathrm{ml}^{-1}$ ) and the sandflat $\left(1.67 \mathrm{mg} \mathrm{ml}^{-1}\right)$. However, no significant differences $(P>0.05)$ were detected between the superficial sediments and the deeper layer if data were expressed on a volume basis (Fig. 2, below). An exponential fit describes the decline of the TOC concentration (in milligrams per milliliter) as a function of the distance from the mussel bed. The curves for the surface sediment TOC $=3.71 \mathrm{e}^{-0.0003 x}\left(r^{2}=0.9170\right)$ and for the $7-9 \mathrm{~cm}$ layer TOC $=3.72 \mathrm{e}^{-0.0003 x}\left(r^{2}=0.8653\right)$ can be fitted by nearly the same equation, with $x$ representing the distance in meters. TOC concentration was significantly correlated with mud content $(r=0.2882 ; n=64 ; P<0.05)$.

\section{Number of bacteria}

The total bacterial counts (TBC) in superficial sediments and in the 7-9 $\mathrm{cm}$ layer are shown in Fig. 3 (above). At the surface the annual average bacterial number ranged from $1.7 \times 10^{8}$ counts $\mathrm{ml}^{-1}$ at station $\mathrm{A}$ in the mussel bed to $8.5 \times 10^{6}$ counts $\mathrm{ml}^{-1}$ at the sandflat station $\mathrm{F}$.
The numbers of bacteria at the stations in the mussel bed and the sandflat differ significantly $(P<0.05)$ as revealed by $t$-test analyses. Additionally, in the mussel bed the numbers varied annually within a wide range (from $4.8 \times 10^{5}$ to $3.8 \times 10^{8}$ counts $\mathrm{ml}^{-1}$ ), whereas in the sandflat the annual variation was only from $5.5 \times 10^{6}$ to $2.7 \times$ $10^{7}$ counts $\mathrm{ml}^{-1}$. Only in the $7-9 \mathrm{~cm}$ layer did the values decline with increasing distance from the mussel bed (Spearman's $r=-0.3463, P<0.05)$. An exponential fit by the equation $\mathrm{TBC}=2 \times 10^{7} \mathrm{e}^{0.0009 \times}\left(r^{2}=0.4848\right)$ describes the interrelation between the number of bacteria (counts $\mathrm{ml}^{-1}$ ) and the distance $x(\mathrm{~m})$ from the mussel bed. Bacterial numbers were positively correlated to mud content (Pearson's $r=0.3106, P<0.001 ; n=104$ ).

Assuming that the cell volume did not vary significantly with time and space, the bacterial biomass carbon can be calculated according to Cammen (1991). The bacterial biomass carbon was determined using a per-cell carbon of $20 \mathrm{fg}$ (Lee and Fuhrman 1987). In the mussel bed a bacterial biomass carbon of $8 \mu \mathrm{g} \mathrm{C} \mathrm{ml}^{-1}$ in the 0-2 $\mathrm{cm}$ layer and $4 \mu \mathrm{g} \mathrm{C} \mathrm{ml}-1$ in the deeper layer was found. The corresponding values for the sandflat sediments were $2 \mu \mathrm{g} \mathrm{C} \mathrm{ml}-1$ and $0.4 \mu \mathrm{g} \mathrm{C} \mathrm{ml}{ }^{-1}$, respectively. In the muddy sediment about $0.50 \%$ of the total TOC was identified as bacterial biomass, whereas in the sand- 
flat on average only $0.13 \%$ of the TOC originated from bacterial biomass.

\section{Microbial biomass}

The microbial biomass, expressed as the total adenylate concentration (in micrograms per milliliter) varied within about 4 orders of magnitude (Fig. 3, middle). The median values in the surface sediment ranged from $0.9 \mu \mathrm{g}$ $\mathrm{ml}^{-1}$ in the sandflat to about $2.3 \mu \mathrm{g} \mathrm{ml}^{-1}$ in the mudflat. Differences were not significant on a $95 \%$ level. The At values of the 7-9 $\mathrm{cm}$ layer were generally lower than those of the surface sediment, but the difference was statistically not significant $(P>0.05)$. The variability of the values was higher in the mussel bed (coefficient of variance $(\mathrm{CV}=72 \%)$ than in the sandflat $(\mathrm{CV}=62 \%)$. The trend analysis by a Spearman's rank test showed no significant correlation between At concentration and distance from the mussel bed. However, using log-transformed data we found a significant correlation between At concentration and mud content $(r=0.2437 ; n=87$; $P<0.05)$.

Assuming an ATP/C ratio of 171 (Karl 1980), the total microbial biomass $\mathrm{C}$ was calculated as $0.13 \mathrm{mg} \mathrm{C} \mathrm{ml}^{-1}$ for the surface sediment, and $0.07 \mathrm{mg} \mathrm{ml}^{-1}$ for the deeper layer of the mudflat, compared to $0.08 \mathrm{mg} \mathrm{ml}^{-1}$ for the sandflat. Surprisingly, the proportion of the microbial biomass $\mathrm{C}$ related to the TOC concentration was found in the narrow range of $2.9-3.1 \%$, independent of the type of sediment.

\section{Energy metabolism}

In the present study, the AEC in the surface sediments varied between 0.35 at the mussel bed stations, 0.72 at the sandflat, and 0.36 and 0.57 in the deeper layer, respectively (Fig. 3, below). A $t$-test revealed that this difference between the mudflat and the sandflat is significant $(P<0.001)$. Again, the variability of the AEC was higher in the mussel bed $(\mathrm{CV}=33 \%)$ than at the sandflat station $(\mathrm{CV}=17 \%)$. In the surface sediment AEC increased significantly with increasing distance from the mussel bed (Spearman $r=0.4324 ; P<0.01$ ). The relationship between AEC and distance $x(\mathrm{~m})$ can be described by an exponential fit $\mathrm{AEC}=0.3257 \mathrm{e}^{-0.0003 x}$ $\left(r^{2}=0.8911\right)$. AEC was negatively correlated with mud content $\quad(r=-0.2884, \quad n=87 ; \quad P<0.01)$, with TOC $(r=-0.2670, n=56 ; P<0.05)$, and with the number of bacteria $(r=-0.2221, n=87 ; P<0.01)$.

\section{Substrate utilization patterns}

The benthic microbial communities of the mussel bed and the sandflat are characterized by different substrate utilization patterns. The microbial community of the mussel bed reached maximal absorption after $24 \mathrm{~h}$. The

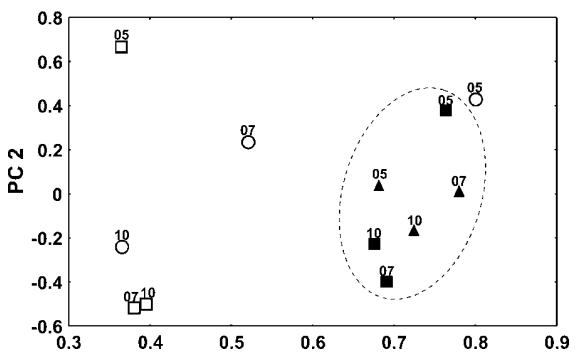

Fig. 4 Principal component analysis (PCA) showing variation in substrate utilization pattern of different stations. 05 May 1995; 07 July 1995; 10 October 1995. Scores for the different stations: black squares station $\mathrm{A}$; black triangles station $\mathrm{B}$; circles station $\mathrm{E}$; white squares station F. Dotted line indicates the cluster of mussel bed stations

absorption after $24 \mathrm{~h}$ ran to $98 \%( \pm 28 \%)$ of the values measured after $48 \mathrm{~h}$ of inoculation. The ability of the sandflat community to grow on the different carbon sources was measured as only $52 \%( \pm 9 \%)$ after $24 \mathrm{~h}$, compared to the maximum after $48 \mathrm{~h}$. While the microorganisms of the mussel bed metabolized only 69 of 95 offered $\mathrm{C}$ sources after an incubation time of $48 \mathrm{~h}$, the microbial sandflat community showed a turnover of 85 of the 95 offered C sources. The Margalef index as a measure of the functional diversity of microbial communities was higher in the sandflat $(7.3 \pm 1.3)$ than in the sediment of the mussel bed (6.2 \pm 1.4$)$. Comparing the general capacity of the investigated microbial communities to utilize different substrate groups, we could not prove any differences for carbohydrates, carboxylic acids, amides, amino acids and miscellaneous substances (see Zak et al. 1994). In contrast, the capability to degrade polymers such as glycogen or cyclodextrin was significantly lower for the microbial community of the mussel bed.

The PCA for the samples taken from the mussel bed stations (A and B), the station E at a distance of $1500 \mathrm{~m}$ from the mussel bed, and the sandflat $(\mathrm{F})$ after $48 \mathrm{~h}$ of incubation is shown in Fig. 4. The substrate utilization patterns of mussel bed samples were similar among each other but were clearly distinct from the microbial sandflat community. The substrate utilization patterns of station E were characterized by a surprisingly high temporal variation. In spring it was quite similar to the patterns of the mussel bed stations A and B; in summer it was intermediate between the patterns of the microbial mussel bed community and the microbial sandflat community, and in autumn the pattern of the microbial community on station $\mathrm{E}$ resembled more those of the microbial sandflat community.

\section{Discussion}

According to our results, the selective filtration by the blue mussel Mytilus edulis and the production of faeces and pseudofaeces have a decisive effect on TOC concen- 
tration and sediment grain size distribution in surrounding sandflats. The consequences of biodeposition are expected to be of great importance not only for the circulation of organic matter and nutrients (Kautsky and Evans 1987; Grenz et al. 1990) but also for benthic organisms. To calculate the adenylate concentration which is considered as a global measure of microbial biomass (bacteria, micro-meiofauna/-flora), we applied the sum of AMP, ADP and ATP according to Davis and White (1980) instead of the commonly used ATP content (e.g. Vosjan et al. 1987). ATP is assumed to reflect only microbial organisms in an active state and to neglect all organisms that are a part of the dormant population amounting to $60 \%-90 \%$ of a microbial community (Paul and Voroney 1983).

In our study the microbial biomass did not differ significantly between the sample stations, due to the variation in the values. Microbial $\mathrm{C}$ values of about $2.9-3.1 \%$ relating to the sediment carbon concentration indicate approximately the same biomass/nutrient ratio for all sampling sites, independent of the organic matter quality. This relationship between microbial biomass, microbial production and organic matter in sediments has been described by several authors (e.g. Cole et al. 1988; Cammen 1991).

The observed positive relationship between TBC and organic $\mathrm{C}$ has also been described by different authors (e.g. Dale 1974; DeFlaun and Mayer 1983; Findlay et al. 1990). In addition to the different explanations of these authors, we argue that the higher bacterial numbers in the mussel bed might also be due to an accumulation of bacteria by the mussels from the water column. Pelagic microorganisms contribute to the nutrition of the mussels, but a large amount of the infiltrated material is rejected by the mussels via faeces and pseudofaeces (Birkbeck and McHenery 1982). The rejected detritus mainly consists of fine sediments and organic material associated with microorganisms (Dankers and Zuidema 1995). In the mussel bed $0.5 \%$ of the mean bacterial $C$ accounted for the total sediment $\mathrm{C}$, whereas in the sandflat the part of bacterial $\mathrm{C}$ on total sediment $\mathrm{C}$ amounts to $0.13 \%$ on average. Meyer-Reil (1983) and Cammen (1982) also reported values of less than $2 \%$ for coastal marine sediments. Cammen (1991) confirms our results by proving higher values in the mudflat than in sandy sediments.

The bacterial $\mathrm{C}$ accounted for $8 \%$ of the total microbial biomass $\mathrm{C}$ in the surface sediment of the sandflat, and for $24 \%$ in the muddy mussel bed. An increasing input of organic matter and an accumulation of fine material by the mussels create an environment that is characterized by anaerobic conditions. In this environment bacteria are favoured compared to meiofauna and other organisms in the microbial community. Similar results were reported by Meyer-Reil (1983), who also found an increasing bacterial biomass related to total microbial biomass when hypoxic or anoxic situations occurred.

Despite a higher microbial biomass in the mussel bed sediments, the energy status (AEC) of the microbial community in the mussel bed was lower compared to the sandflat system. This paradoxical phenomenon has also been described by other authors. For instance, Boucher and Clavier (1990), investigating mangrove ecosystems in Caledonia, showed that ATP values were significantly lower in muddy sediments than in white-sand and gray sand bottoms. The carbon/ATP ratio, as a measure of biological microbial activity, also decreased significantly with increasing mud and interstitial water content. Apparently, microbial organisms in the muddy sediment may be under greater physico-chemical stress than in the sandflat (Chocair and Albright 1981). In the sediments of the mussel bed the scale and intensity of disturbances are additionally influenced by frequently changing conditions, e.g. the pulse of fresh inorganic and organic material deposited by the mussels. This relatively ephemeral habitat favors a microbial population which is able to adapt permanently to a changing microscale environment (Andrews and Harris 1986). The carbon-source utilization profiles confirm that the microbial population in the mussel bed is adapted to this unstable conditions. The so-called r-strategists grow rapidly under uncrowded, nutrient-rich conditions as could be proven for the mussel bed. The substrate-utilization pattern (faster growth, lower functional diversity) gives some evidence that $r$-strategists are dominating in the mussel bed. The metabolically active part of the microbial population is covered by dormant or dying biomass, which does not contribute to any decomposition process (e.g. Paul and Voroney 1983). However, the AEC does not reflect any biomass in a dormant or dying state. Furthermore, the energetical outcome of microbial metabolism in an anoxic environment as it occurs in the mussel bed is supposed to be several times lower than the energetical outcome of microbial metabolism in an oxic environment. Our result is supported by Jewson and Dokulil (1982) who also found a decreasing AEC in sediments despite increasing biomass during and beyond an algal bloom in a Northern Ireland lake.

In contrast, the microbial community in the sandflat is mainly dominated by $\mathrm{K}$-strategists, adapted to a lower input of nutrients (Andrews and Harris 1986). Despite large-scale effects, K-communities are characterized by a rather stable dominating metabolically active part concerning time and space (Pianka 1970). Consequently, AEC increases despite a decreasing biomass. The higher functional diversity (Margalef index of carbon utilization profile) of the sandflat community supports these results. The carbon utilization profile indicates a retarded growth accompanied by a higher potential to metabolize more substrates than the mudflat community.

The temporal response of the microbial community at the sampling station $\mathrm{E}$ to the input of organic material reflects the impact of mussel beds on the physiological profile of the microbial community. The deviating temporal physiological response of the microbial community at the sampling station $\mathrm{E}$ is due to a younger mussel bed which had established near the sampling station $E$ in spring 1995. At that time the microbial substrate utiliza- 
tion profile is quite similar to the pattern of the community at mussel bed stations A and B. In summer 1995 these young mussels were predated by herring gulls (Larus argentatus) and oyster catchers (Haematopus ostrategus), which caused a decisive decrease in the average mussel biomass (Hilgerloh et al. 1997). A decreasing mussel biomass resulted in a substrate utilization profile that was an intermediate between the mussel bed stations and the reference $\mathrm{F}$ in the sandflat. Due to predation, the new mussel bed had more or less disappeared in autumn 1995 and the benthic microbial community at station E became more similar to a typical sandflat community. Obviously the deposited faeces of these new mussels influenced the microbial community; however, the extent of the timescale of microbial reaction on such events remains unknown and should be studied in a further experiment.

In conclusion, the biodeposits of mussels influence the concentration of particulate organic carbon as well as the sediment grain size distribution, the bacterial numbers and the total microbial biomass and activity in the vicinity of a mussel bed. The decomposition of the deposited organic material in the mussel bed is dominated by bacteria, especially when anaerobic conditions occur, whereas towards the sandflat an increasing proportion of benthic meiofauna takes part in mineralization processes. The lower energy charges in the muddy sediments indicate a lower proportion of active cells. The microorganisms in the mussel bed are under permanent physicochemical stress. Compared to the sandflat, we observed a higher amplitude of all measured parameters in the mussel bed. This observation indicates an adaptation of the microbial community to the pulses of organic matter availability, which favors the occurrence of r-selected communities. In the sandflat, large-scale effects such as hydrodynamic factors (e.g. storms, heavy waves, etc.) permanently alter the mussel bed ecosystem from a microorganism's point of view, requiring a great capacity to meet physical environmental changes. The physiological impact such as nutrition sources merely seems to be of minor importance.

Acknowledgements The authors thank Kim Knauth-Köhler and Thomas Leu for their assistance in sampling and for their help in the lab, and Alexander Bartholomä for providing Fig. 1. We are grateful to the crews of the research vessels "FK Senckenberg" and "Terramare" for their safe guiding through the dangers of the Wadden Sea. Thanks are also due to Dr. Liebezeit and the staff of FZ Terramare in Wilhelmshaven, where the experiments were performed according to the current laws of Germany. This work was supported by grant FKZ 03F0112A (the project ELAWAT) of the Bundesministerium für Bildung, Wissenschaft, Forschung und Technologie (BMBF).

\section{References}

Albers BP, Knauth-Köhler K (1998) Bestimmung der funktionalen Diversität anhand von Substratverwertungsmustern ("BIOLOG"). In: Vereinigung für Allgemeine und Angewandte Mikrobiologie (VAAM) (ed) Mikrobiologische Charakterisierung aquatischer Sedimente. Oldenbourg, Munich, pp 216-224
Albers BP, Stoeck T (1998) Extraktion und Bestimmung von AMP, ADP und ATP. In: Vereinigung für Allgemeine und Angewandte Mikrobiologie (VAAM) (ed) Mikrobiologische Charakterisierung aquatischer Sedimente. Oldenbourg, Munich, pp 36-46

Albers BP, Rackwitz R, Raubuch M, Zelles L (1996) Adenylates and adenylate energy charge. In: Schinner F, Öhlinger R, Kandeler E, Margesin R (eds) Methods in soil biology. Springer, Berlin Heidelberg New York, pp 246-252

Andrews JH, Harris RF (1986) r- and K-selection and microbial ecology. Adv Microb Ecol 9:99-147

Asmus H, Ruth M (1994) Muscheln: Biologie, Bänke, Fischerei und Kulturen. In: Lozan LJ, Rachor E, Reise K, Westernhagen Hv, Lenz W (eds) Warnsignale aus dem Wattenmeer. Springer, Berlin Heidelberg New York, pp 127-132

Atkinson DE, Walton GM (1976) Adenosine triphosphate conserversion in metabolic regulation. J Biol Chem 242:3239-3241

Birkbeck TH, McHenery JG (1982) Degradation of bacteria by Mytilus edulis. Mar Ecol 72:7-15

Boucher G, Clavier J (1990) Contribution of benthic biomass to overall metabolism in New Caledonia lagoon sediments. Mar Ecol Prog Ser 64:271-280

Cammen LM (1982) Effect of particle size on organic content and microbial abundance within four sediments. Mar Ecol Prog Ser 9:273-280

Cammen LM (1991) Annual bacterial production in relation to benthic microalgal production and sediment oxygen uptake in an intertidal sandflat and an intertidal mudflat. Mar Ecol Prog Ser 71:13-15

Chocair JA, Albright LJ (1981) Heterotrophic activities of bacterioplankton and bacteriobenthos. Can J Microbiol 27:26592666

Cole JJ, Stuart F, Michael LP (1988) Bacterial production in fresh and sea water ecosystems, a cross system overview. Mar Ecol Prog Ser 43:1-10

Dale NG (1974) Bacteria in intertidal sediments: factors related to their distribution. Limnol Oceanogr 19:509-518

Dankers N, Zuidema DR (1995) The role of the mussel (Mytilus edulis L.) and mussel culture in the Dutch Wadden Sea. Estuaries $18: 71-80$

Dankers N, Dame R, Kersting K (1989) The oxygen consumption of mussel beds in the Dutch Wadden Sea. Sci Mar 53:473-476

Davis WM, White DC (1980) Fluorometric determination of adenosine nucleotide derivates as measures of the microfouling, detrital and sedimentary microbial biomass and physiological status. Appl Environ Microbiol 40:539-548

DeFlaun MF, Mayer LM (1983) Relationship between bacteria and grain surfaces in intertidal sediments. Limnol Oceanogr $28: 873-881$

Dye AH (1983) A method for the quantitative estimation of bacteria from mangrove sediments. Estuarine Coast Shelf Sci 17: 207-212

Epstein SS, Rossel J (1995) Enumeration of sandy sediment bacteria: search for optimal protocol. Mar Ecol Prog Ser 117:289298

Findlay RH, Trexler MB, White DC (1990) Response of a benthic microbial community to biotic disturbance. Mar Ecol Prog Ser 62:135-148

Grenz C, Hermin MN, Baudinet D, Daumas R (1990) In situ biochemical and bacterial variation of sediments enriched with mussel biodeposits. Hydrobiology 207:153-160

Hilgerloh G, Herlyn M, Michaelis H (1997) The influence of predation by herring gulls Larus argentatus and oystercatchers Haematopus ostralegus on a newly established mussel Mytilus edulis bed in autumn and winter. Helgoländer Meeresunters 51:173-189

Janke K, Kremer BP (1990) Das Watt - Lebensraum, Tiere und Pflanzen. Franckh'sche Verlagshandlung, Stuttgart

Jewson DH, Dokulil M (1982) Adenylate energy charge measurements in freshwater microbial studies. J Ecol 70:595-606

Karl DM (1980) Cellular nucleotide measurement and applications in microbial ecology. Microbiol Rev 44:739-796 
Kautsky N, Evans S (1987) Role of biodeposition by Mytilus edul$i s$ in the circulation of matter and nutrients in a Baltic coastal ecosystems. Mar Ecol Prog Ser 38:201-212

Lee S, Fuhrman JA (1987) Relationships between biovolume and biomass of naturally derived marine bacterioplankton. Appl Environ Microbiol 53:1298-1303

Meyer-Reil LA (1983) Benthic response to sedimentation events during autumn to spring at a shallow water station in the Western Kiel Bight. Mar Biol 77:247-256

Paul EA, Voroney RP (1983) Field interpretation of microbial biomass activity measurements. In: Klug MJ, Reddy CA (eds) Current perspectives in microbial ecology. ASM, Washington, pp 509-514

Pianka ER (1970) On r- and K-selection. Am Nat 104:592-597
Prieur D, Mevel G, Nicolas JL, Plusquellec A, Vigneulle M (1990) Interactions between bivalve moluscs and bacteria in the marine environment. Oceanogr Mar Biol Annu Rev 28:277-352

Sachs L (1992) Angewandte Statistik: Anwendung statistischer Methoden. Springer, Berlin Heidelberg New York

Stuart VR, Newell RC, Lucas MI (1982) Conversion of kelPdebris and faecal material from mussel Aulocomya ater by marine microorganisms. Mar Ecol Prog Ser 7:47-57

Vosjan JH, Nieuwland G, Ernst W, Bluszcz T (1987) Shipboard comparison of two methods of extraction and measurements of ATP applied to antarctic water samples. Neth J Sea Res 21:107-112

Zak JC, Willig MR, Moorhead DL, Wildman HG (1994) Functional diversity of microbial communities: a quantitative approach. Soil Biol Biochem 26:1101-1108 